\title{
Enzyme properties and thermal stability of horseradish peroxidase (HRP-DL)
}

\author{
Te Wang ${ }^{1,2}$, Jing Tian ${ }^{1}$, Tingting $\mathrm{Li}^{1}$, Jian $\mathrm{Li}^{1}$ and Linghua Zhang ${ }^{1, \mathrm{a}}$ \\ ${ }^{1}$ Environmental Science and Engineering College, Dalian Maritime University, Dalian, China \\ ${ }^{2}$ Liaoning Institute of Science and Technology, Benxi, China
}

Keywords: Horseradish peroxidase, thermal stability, protective agent, stress resistance, Ectione.

\begin{abstract}
Horseradish peroxidase (HRP) is widely used in biological engineering, wastewater treatment, enzyme-linked immunosorbent assay and other fields. It is great significance to study its enzyme properties, stress resistance and protective agent. In order to provide good quality HRP, and protection method of HRP thermal stability, horseradish peroxidase (HRPDL) was extracted and purified from horseradish which was collected from Dalian, China in this paper. It was investigated that the enzyme characterization, thermal stability, thermal protection from thermal stability protection agents of HRP-DL. The optimum temperature of HRP-DL was $30^{\circ} \mathrm{C}$, the optimum $\mathrm{pH}$ of HRP-DL was 5.5. HRP-DL enzyme activity was inhibited significantly by $\mathrm{NaCl}$. HRP-DL was activated by $\mathrm{Ca}^{2+}, \mathrm{Mn}^{2+}, \mathrm{Zn}^{2+}, \mathrm{Pb}^{2+}, \mathrm{Mg}^{2+}, \mathrm{Go}^{2+}$, $\mathrm{Fe}^{3+}$, and inhibited by $\mathrm{K}^{+}, \mathrm{Cu}^{2+}, \mathrm{Hg}^{2+}, \mathrm{Ag}^{+}, \mathrm{Fe}^{2+}$ in different degree. When HRP-DL was processed at the temperature greater than or equal to $35^{\circ} \mathrm{C}$, the residual enzyme activity was reduced. The HRP-DL residual enzyme activity increase $49.3 \%$ when added $1 \mathrm{mmol} / \mathrm{L}$ Ectoine and heat treatment at $60{ }^{\circ} \mathrm{C}$ for $15 \mathrm{~min}$. The study of HRP-DL enzyme characterization provided the basis for its practical application. Ectoine as HRP-DL thermally stable protective agent has advantages such as the use of less, the effect is significant.
\end{abstract}

\section{Introduction}

Horseradish peroxidase (HRP, EC 1.11.1.7) is a glycoprotein complex enzyme of oxidoreductases, it is supplemented by radical iron porphyrin heme protein, $\mathrm{H}_{2} \mathrm{O}_{2}$ exists as hydrogen donor can catalyze the reduction polymerization of phenol, aniline and its derivatives ${ }^{[1,2]}$. HRP is currently mainly extracted from the roots of horseradish. HRP is used as a reagent for organic synthesis, biotransformation, as well, as in coupled enzyme assays, chemiluminescent assays, immunoassays and the treatment of waste waters. And it is also widely used in medical diagnostic, biosensing, bioremediation and biotechnological applications ${ }^{[3-6]}$. In recent years, HRP is widely used in the field of biochemistry, enzyme-linked immunosorbent detection ${ }^{[7,8]}$. Because of the wide application of HRP, it is great significance to study its enzyme properties, stress resistance and protective agent.

The reported of improving stability of HRP against the inverse environment, such as through the analysis of HRP Soret band absorption spectrum, tryptophan intrinsic fluorescence and ANS fluorescence, it revealed that enzyme stabilizers can significantly reduce the degree of denaturation of

a Corresponding author : dlzlh2008@163.com 
HRP under heating so as to maintain relatively stable native conformation. After screening found magnesium sulfate and gelatin mixture can significantly improve the thermal stability of HRP. HRP added magnesium sulfate and gelatin mixture still maintain $89 \%$ of active after incubated in $50{ }^{\circ} \mathrm{C}$ for 80 hours, and still maintain $57 \%$ of active under normal temperature for 90 days ${ }^{[9]}$. The literature reported that by obtaining the stable horseradish peroxidase-dextran aldehyde conjugates can improve the stability of HRP against the inverse environment such as high temperature. Multipoint covalent bonding of dextran to horseradish peroxidase caused the formation of a conjugate whose thermal stability was highest at $\mathrm{pH} 7$ and the molar ratios of HRP and dextrans provided to obtain the conjugate was $1 / 10^{[10]}$. However, these methods still have limitations in practical applications such as poor resistance activity, and large amount of protective agent.

In this paper, horseradish peroxidase (HRP-DL) was extracted and purified from horseradish which was collected from Dalian, China. The optimum temperature and $\mathrm{pH}$ of HRP-DL was investigated. Effect of $\mathrm{NaCl}$ concentration and several metal ions on the enzyme activity of HRP-DL was investigated. Thermal stability of HRP-DL was investigated. The protective effect of different concentration of Ectoine on thermal stability of HRP-DL was compared.

\section{Materials and methods}

\subsection{Materials}

Experimental medicines and reagents:

Horseradish: collected from Dalian, China. Tetramethylbenzidine dihydrochloride (TMB 2HCl) purchased from Biological Engineering Company Limited (Dalian). Ectoine purchased from Germany BIOMOL company.

\subsection{The extraction and measurement of purity of HRP-DL}

Horseradish roots were collected from Dalian, China. HRP was extracted by the method in reference $^{[1]}$, SDS-PAGE electrophoresis was executed by the method in reference ${ }^{[12]}$, protein concentration was measured by the method in reference ${ }^{[13]}$.

\subsection{Measurement of HRP enzyme activity}

The enzyme activity of HRP was measured using TMB $2 \mathrm{HCl}$ as chromogenic substrate by the method in reference ${ }^{[10,14]}$.

\section{Results and discussion}

\subsection{Horseradish peroxidase (HRP-DL) properties}

According to the method of "2.2", Horseradish peroxidase was extracted and purified, and SDS-PAGE electrophoresis was executed, the result showed that a single band and meant the horseradish peroxidase is a purification material. Apparent molecular weight approximately was $44.1 \mathrm{kD}$, the value of RZ approximately was 3.1 , specific activity was $1266.7 \mathrm{U} / \mathrm{mg}$. The enzyme was named HRPDL.

Optimum temperature of HRP-DL:

The enzyme activity of HRP-DL was measured at different temperatures $\left(15{ }^{\circ} \mathrm{C}-65{ }^{\circ} \mathrm{C}\right)$, the result was shown in Figure 1. As shown in Figure 1, the optimum temperature of HRP-DL was $30{ }^{\circ} \mathrm{C}$, measurement of the enzyme activity was the highest (the relative enzyme activity is $100 \%$ ) at this temperature; the relative enzyme activity of HRP-DL was $9.7 \%$ at $60{ }^{\circ} \mathrm{C}$. 


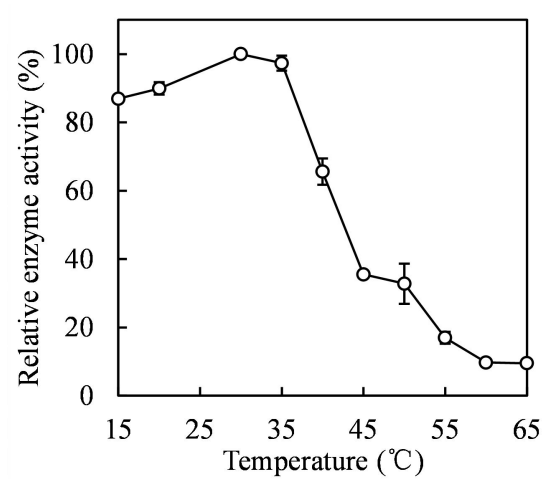

Figure 1. Effect of temperature on the enzyme activity of HRP-DL.

Note: the enzyme activity of HRP-DL was represented by relative enzyme activity, which was set $100 \%$ at $30{ }^{\circ} \mathrm{C}$.

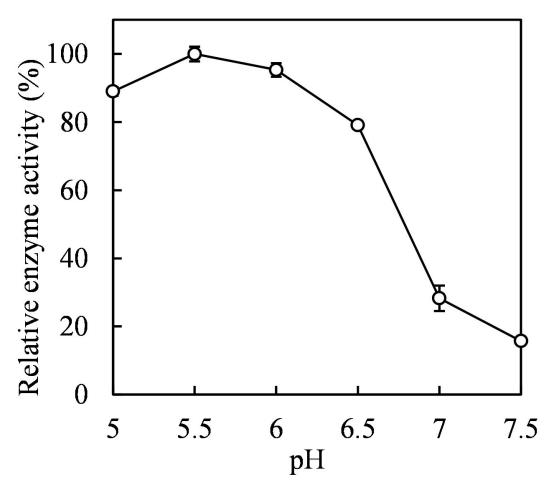

Figure 2. Effect of $\mathrm{pH}$ on the enzyme activity of HRP-DL.

Note: the enzyme activity of HRP-DL was represented by relative enzyme activity, which was set $100 \%$ at $\mathrm{pH} 5.5$.

Optimal $\mathrm{pH}$ of HRP-DL:

The $\mathrm{pH}$ of HRP-DL enzyme activity measurement system were adjusted to 5.5, 6, 6.5, 7, 7.5 and 8 , according to the method of "2.3", the enzyme activity of HRP-DL was measured, the result was shown in Figure 2. As shown in Figure 2, the optimal pH of HRP-DL was 5.5.

Effect of $\mathrm{NaCl}$ concentration on the enzyme activity of HRP-DL

The $\mathrm{NaCl}$ concentration of HRP-DL enzyme activity measurement system were adjusted to $0,1,2$, $3,4,5$ and $6 \mathrm{~mol} / \mathrm{L}$, according to the method of "2.3", the activity of HRP-DL was measured, the result was shown in Figure 3. As shown in Figure 3, with the increasing of $\mathrm{NaCl}$ concentration in the reaction system, enzyme activity was gradually decreased; When the $\mathrm{NaCl}$ concentration was $4 \mathrm{~mol} / \mathrm{L}$, the relative enzyme activity was $50.3 \%$.

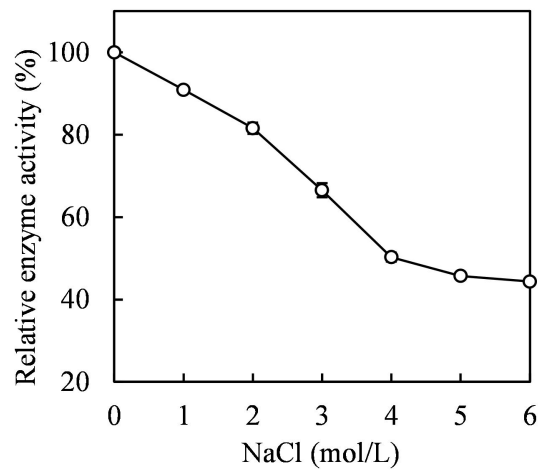

Figure 3. Effect of $\mathrm{NaCl}$ on the enzyme activity of HRP-DL.

Note: the enzyme activity of HRP-DL was represented by relative enzyme activity, which was set $100 \%$ when $\mathrm{NaCl}$ was not added.

Effect of metal ions on the enzyme activity of HRP-DL

In the HRP-DL enzyme activity measurement system, adding different concentration of $\mathrm{CaCl}_{2}$ 、 $\mathrm{MnCl}_{2} 、 \mathrm{KCl} 、 \mathrm{ZnSO}_{4} 、 \mathrm{~Pb}\left(\mathrm{CH}_{3} \mathrm{COO}\right)_{2} 、 \mathrm{MgCl}_{2} 、 \mathrm{CuSO}_{4} 、 \mathrm{GoCl}_{2} 、 \mathrm{HgCl}_{2} 、 \mathrm{AgCl}_{2} 、 \mathrm{FeSO}_{4} 、 \mathrm{FeCl}_{3}$, respectively. According to the method of "2.3", the activity of HRP-DL was measured, selecting the significant effect date, the result was shown in Table 1. As shown in Table 1, HRP-DL was activated by $\mathrm{Ca}^{2+}, \mathrm{Mn}^{2+}, \mathrm{Zn}^{2+}, \mathrm{Pb}^{2+}, \mathrm{Mg}^{2+}, \mathrm{Go}^{2+}, \mathrm{Fe}^{3+}$, and inhibited by $\mathrm{K}^{+}, \mathrm{Cu}^{2+}, \mathrm{Hg}^{2+}, \mathrm{Ag}^{+}, \mathrm{Fe}^{2+}$ in different degree. 
Table 1. Effect of metal ions on enzyme activity of HRP-DL.

\begin{tabular}{cccc}
\hline $\begin{array}{c}\text { Metal ions(Ion } \\
\text { concentration) } \\
\text { Comparison }\end{array}$ & $\begin{array}{c}\text { Relative enzyme } \\
\text { activity(\%) }\end{array}$ & $\begin{array}{c}\text { Metal ions(Ion } \\
\text { concentration) } \\
\text { Comparison }\end{array}$ & $\begin{array}{c}\text { Relative enzyme } \\
\text { activity(\%) }\end{array}$ \\
\hline $\mathrm{Ca}^{2+}(4 \mathrm{mmol} / \mathrm{L})$ & $356.3 \pm 1.3$ & $\mathrm{Cu}^{2+}(0.01 \mathrm{mmol} / \mathrm{L})$ & $91.2 \pm 0.8$ \\
$\mathrm{Mn}^{2+}(5 \mathrm{mmol} / \mathrm{L})$ & $170 \pm 1$ & $\mathrm{Co}^{2+}(5 \mathrm{mmol} / \mathrm{L})$ & $306.7 \pm 1.5$ \\
$\mathrm{~K}^{+}(5 \mathrm{mmol} / \mathrm{L})$ & $92.5 \pm 0.7$ & $\mathrm{Hg}^{2+}(0.01 \mathrm{mmol} / \mathrm{L})$ & $73.9 \pm 1.1$ \\
$\mathrm{Zn}^{2+}(5 \mathrm{mmol} / \mathrm{L})$ & $513.7 \pm 1.8$ & $\mathrm{Ag}^{+}(0.001 \mathrm{mmol} / \mathrm{L})$ & $71.1 \pm 0.9$ \\
$\mathrm{~Pb}^{2+}(6 \mathrm{mmol} / \mathrm{L})$ & $491.8 \pm 1.7$ & $\mathrm{Fe}^{2+}(4 \mathrm{mmol} / \mathrm{L})$ & $66.1 \pm 0.7$ \\
$\mathrm{Mg}^{2+}(4 \mathrm{mmol} / \mathrm{L})$ & $230.6 \pm 1.4$ & $\mathrm{Fe}^{3+}(5 \mathrm{mmol} / \mathrm{L})$ & $2568.9 \pm 2.1$ \\
\hline
\end{tabular}

Note: the enzyme activity of HRP-DL was represented by relative enzyme activity, which was set $100 \%$ when the metal ions was not added.

\subsection{The thermal stability of HRP-DL}

HRP-DL was processed at $30,35,40,45,50,55$ and $60{ }^{\circ} \mathrm{C}$ for $15 \mathrm{~min}$, respectively, placed at room temperature for $15 \mathrm{~min}$, then according to the method of "2.3", the enzyme activity of HRP-DL was measured, the results was shown in Figure 4. As shown in Figure 4, when HRP-DL was processed at the temperature greater than or equal to $35^{\circ} \mathrm{C}$, the residual enzyme activity was reduced; when HRP$\mathrm{DL}$ was processed at $60{ }^{\circ} \mathrm{C}$, the relative enzyme activity was merely $7.6 \%$.

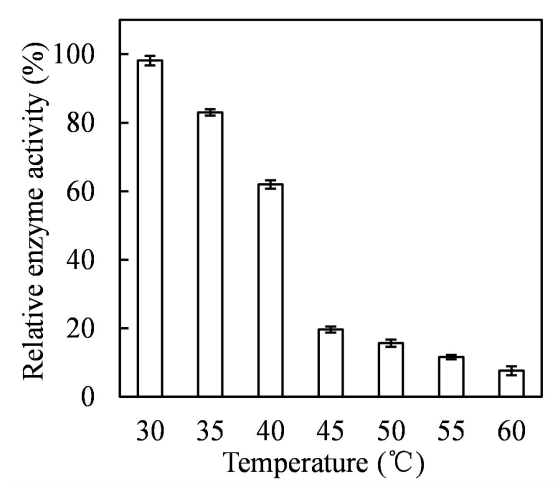

Figure 4. The thermal stability of HRP-DL.

Note: the enzyme activity of HRP-DL was represented by relative enzyme activity, which was set $100 \%$ at $30{ }^{\circ} \mathrm{C}$.

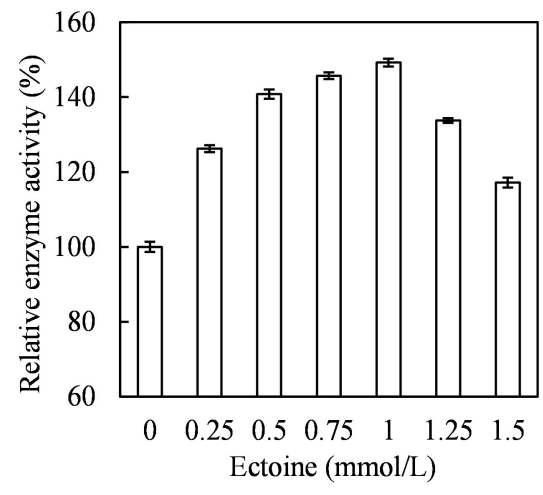

Figure 5. The thermal stability of Ectoine on HRP-DL.

Note: the enzyme activity of HRP-DL was represented by relative enzyme activity, which was set $100 \%$ when Ectoine was not added.

\subsection{Thermal protection of Ectoine on HRP-DL}

The HRP-DL enzyme activity measurement system was added different concentration of Ectoine, respectively. According to the method of "2.3", the enzyme activity of HRP-DL was measured at 60 ${ }^{\circ} \mathrm{C}$, the results was shown in Figure 5. As shown in Figure 5, different concentration of Ectoine, have thermal protective effect on the enzyme activity at high temperature. The effect was most significant when concentration of Ectoine was $1 \mathrm{mmol} / \mathrm{L}$, and the relative enzyme activity was increased $49.3 \%$ of Ectoine was not added. 


\section{Conclusion}

In this paper, HRP-DL was extracted and purified from horseradish which was collected from Dalian, China. Apparent molecular weight approximately was $44.1 \mathrm{kD}$, the value of $\mathrm{RZ}$ approximately was 3.1 , specific activity was $1266.7 \mathrm{U} / \mathrm{mg}$. The optimum temperature of HRP-DL was $30{ }^{\circ} \mathrm{C}$, the optimum $\mathrm{pH}$ of HRP-DL was 5.5. HRP-DL enzyme activity was inhibited significantly by $\mathrm{NaCl}$. With the increasing of $\mathrm{NaCl}$ concentration in the reaction system, the relative enzyme activity was reduced significantly. HRP-DL was activated by $\mathrm{Ca}^{2+}, \mathrm{Mn}^{2+}, \mathrm{Zn}^{2+}, \mathrm{Pb}^{2+}, \mathrm{Mg}^{2+}, \mathrm{Go}^{2+}, \mathrm{Fe}^{3+}$, and inhibited by $\mathrm{K}^{+}$, $\mathrm{Cu}^{2+}, \mathrm{Hg}^{2+}, \mathrm{Ag}^{+}, \mathrm{Fe}^{2+}$ in different degree. HRP-DL was a high purity peroxidase, and it had salt tolerance. The HRP-DL relative enzyme activity was still $53.8 \%$ when the $\mathrm{NaCl}$ concentration reached $4 \mathrm{~mol} / \mathrm{L}$. The study of HRP-DL enzyme characterization provided the basis for its practical application.

When HRP-DL was processed at the temperature greater than or equal to $35{ }^{\circ} \mathrm{C}$, the residual enzyme activity was reduced. The effect was significant when the final concentration of Ectoine as a heat protective agent was $1 \mathrm{mmol} / \mathrm{L}$, which increased enzyme activity of $49.3 \%$. According to the report, in order to achieve the best thermal stability, $0.1 \mathrm{~g} / \mathrm{L}$ HRP need to add the same concentration of gelatin $(0.1 \mathrm{~g} / \mathrm{L})$ and $180 \mathrm{mmol} / \mathrm{L}$ of magnesium sulfate ${ }^{[9]}$. According to another report, HRP need to add 10 times the molar weighted of dextran provided to obtain the conjugate that has the best thermal stability ${ }^{[10]}$. Ectoine as HRP-DL thermally stable protective agent has advantages such as the use of less, the effect is significant, it has important significance for HRP application in inverse environment.

\section{References}

1. S. Wang, Q. Wang, X.R. Fan, J. Xu, Y. Zhang, J.G. Yuan, H.L. Jin and A. Cavaco-Paulo: Carbohydr. Polym. Forum Vol. 136 (2016), p. 1010-1016

2. L.A. Dahili, I. Kelemen-Horváth and T. Feczkó: Process Biochem. Forum Vol. 50 (2015), p. 1835-1842

3. K. Radhapyari, P. Kotoky and R. Khan: Mater. Sci. Eng. Forum Vol. 33 (2013), p. 583-587

4. A. Attar, L. Cubillana-Aguilera, I. Naranjo-Rodriguez, J.L. Hidalgo-Hidalgo de Cisneros, J.M. Palacios-Santander and A. Amine: Bioelectrochemistry. Forum Vol. 101 (2015), p. 84-91

5. K.C. Fang, C.P. Hsu, Y.W. Kang, J.Y. Fang, C.C. Huang, C.H. Hsu, Y.F. Huang, C.C. Chen, S.S. Li, J.A. Yeh, D.J. Yao and Y.L. Wang: Biosens. Bioelectron. Forum Vol. 55 (2014), p. 294-300

6. A. Khosravi, M. Vossoughi, S. Shahrokhian and I. Alemzadeh: Enzyme Microb. Technol. Forum Vol. 50 (2012), p. 10-16

7. S. Parween and P. Nahar: J. Biosci. Bioeng. Forum Vol. 119 (2015), p. 113-116

8. N.C. Veitch: Phytochemistry. Forum Vol. 65 (2004), p. 249-259

9. X.H. Mao: Screening and mechanism of horseradish peroxidase heat stabilizer. Shanxi, Shaanxi normal university, 2009

10. M. Altikatoglu, C. Arioz, Y. Basaran and H. Kuzu: Cent. Eur. J. Chem. Forum Vol. 7 (2009), p. 423-428

11. J. Fan, C. Li, Y.Q. Ji, B.J. Cheng and L. Jiang: Journal of AnHui Agricultural University. Forum Vol. 25 (1998), p. 313-316

12. U.K. LaemmliB: Nature. Forum Vol. 227 (1970), p. 680-685

13. A.G. Gornall, C.J. Bardawill, M.M. Ant David: J. Biol. Chem. Forum Vol. 177 (1949), p. 751766

14. M. Altikatoglu, H. Kuzu: Pol. J. Chem. Technol. Forum Vol. 12 (2010), p. 12-16 